\title{
Analisis Preferensi Petani Kelapa Sawit dalam Membeli Bibit Kelapa Sawit Bersertifikat di Kabupaten Batu Bara
}

Myrna Pratiwi Nasutiona, Putri Sina Br Tarigan ${ }^{\mathrm{b}}$

aFakultas Agroteknologi, Universitas Prima, Indonesia, email: myrnapratiwi88@gmail.com

${ }^{b}$ Fakultas Agroteknologi, Universitas Prima, Indonesia, email: putrisinabrtrgn@gmail.com

\section{Article Info}

Article history:

Received 10 Desember 2020

Received in revised from 23 Desember 2020

Accepted 28 Desember 2020

DOI:

https://doi.org/10.32938/ag.v6i1.1165

Keywords:

Certified Oil Palm Seeds

Conjoint Analysis

Farmer's Preference

\begin{abstract}
Abstrak
There are several factors that cause farmers to be less aware of the importance of the quality and productivity of oil palm plants, including lack of information and publications, lack of socialization on the use of quality seeds and limited farmer capital. From the producer side, in Indonesia there are several companies that produce certified oil palm seeds at various prices. This company offers seed prices starting from sprouts, 3 month old seeds and seeds more than 9 months old. The large number of certified seedlings offered has made the position of competition between brands to be tighter, which has prompted producers to continue to make good business strategies so that their products in the market can be accepted by consumers, especially palm oil entrepreneurs. The purpose of this study was to analyze the combination of certified seed products, product combination attributes, and farmers' preferences for the use of certified oil palm seeds. The data obtained during the study were processed using conjoint analysis. Research data were taken from 100 farmer respondents. The results of the research on the preferences of certified seed farmers that are very popular are certified seeds with attributes of type Dumpy from PPKS, 3 months old seeds, price range around $R p$. 15.000, getting promotion from seed producers by $25 \%$, very easy access to certified seeds, and it can be planted on surging land types. Farmer's Preference in buying oil palm seeds choose seed price as the most preferred attribute when purchasing certified seeds in Batu Bara District.
\end{abstract}

\section{Pendahuluan}

Bibit bermutu tinggi menjadi salah satu faktor penentu keberhasilan dari usahatani kelapa sawit. Bibit yang digunakan harus berasal dari benih unggul dan bersertifikat. Hal ini menjadi sangat penting karena pembibitan adalah awal kegiatan yang harus dimulai setahun sebelum pindah tanam ke lapangan (Ariyanti, M.,et al, 2017). Banyaknya petani yang menggunakan bibit nonsertifikat menyebabkan rendahnya produktivitas dari perkebunan rakyat. Mendorong petani menggunakan bibit bersertifikat akan mampu menaikkan produktivitas lebih tinggi dan tentunya juga dapat dilakukan pada lahan kebun sawit baru. Peningkatan produktivitas tentunya akan melaju pesat bila penggunaan bibit bersertifikat diikuti dengan penggunaan input produksi lainnya secara baik (Kariyasa, 2015).

Kabupaten Batu Bara, Propinsi Sumatera Utara menempatkan kelapa sawit sebagai salah satu komoditas unggulan. Tanaman kelapa sawit perkebunan rakyat ditanam seluruh kecamatan Batu Bara dengan produksi kelapa sawit TBS tahun 2012 sebesar 174.197 ton dengan total luas tanaman 11.999 Ha (Batu Bara dalam angka, 2013). Dari informasi di tempat penelitian kebanyakan petani sawit menggunakan bibit bersertifikat keluaran Pusat Penelitian Kelapa Sawit PPKS, Socfindo dan Lonsum. Produsen perlu mengetahui selera konsumen dalam menentukan pilihan suka atau tidak suka seorang konsumen terhadap suatu produk. Konsumen menilik kepada informasi yang mereka terima tentang produk dan mempertimbangkan ciri-ciri fisik (atribut) produk sebelum membeli (Simarmata et al, 2019). Selain mendorong petani untuk menggunakan bibit bersertifikat, petani juga dapat menelusuri lebih teliti bibit yang sesuai dengan kriteria serta kualitas yang baik dan berbeda-beda dari masing-masing produsen bibit kelapa sawit yang ada di pasaran.

Preferensi Konsumen (preference customer) diartikan sebagai pilihan suka atau tidak suka oleh seseorang terhadap suatu barang atau jasa yang dikonsumsi. Menurut Kotler (2005), preferensi konsumen menunjukan kesukaan konsumen dari berbagai pilihan produk yang ada. Ketersediaan barang yang terbatas memaksa kita untuk memilih salah satu alternatif pilihan yang mengoptimalkan nilai guna suatu barang. Dengan adanya preferensi konsumen kita bisa menilai tingkat kepuasan konsumen terhadap produk yang telah dihasilkan. Suatu atribut akan dianggap penting jika memberikan manfaat yang sangat diinginkan, tetapi jika semua alternatif yang bersaing mempunyai karakteristik yang sama, maka atribut yang lain akan menentukan pilihan merek (Wijaya, 2008). Atribut yang digunakan dalam analisis ini ada 6 (enam) atribut yaitu jenis bibit, ukuran, harga bibit, promosi, kemudahan akses dan tipe lahan dimana 
tujuannya untuk melihat bagaimana kombinasi dan atribut produk bibit bersertifikat yang menjadi preferensi petani dalam membeli bibit bersertifikat di Kabupaten Batu Bara.

\section{Metode}

2.1. Metode Penentuan Sampel.

Jumlah penduduk Kecamatan Batu Bara adalah 404.988 orang. Jumlah responden yang dibutuhkan adalah 100 orang, penentuan sampel responden berdasarkan rumus Slovin, yaitu:

$$
n=\frac{404.988}{1+(404.988 \times 0.01}=99,97 \text { responden }
$$

Jadi dalam penelitian ini digenapkan 100 responden untuk digunakan sebagai sampel. Data penelitian didapatkan dengan menyebarkan kuesioner dan wawancara langsung ke petani. Metode analisis data yang digunakan adalah metode conjoint analysis.

\subsection{Metode Pengolahan dan Analisis Data} berikut:

Secara umum model analisis konjoin (Malhotra, 2004) yang dapat diformulasikan sebagai

$$
U(X)=\sum_{i=1}^{m i} \sum_{j=1}^{k j} B_{i j} X_{i j}
$$

Dimana :

$\mathrm{U}(\mathrm{x}) \quad=$ utility total

$\beta i j \quad=$ part worth atau nilai kegunaan dari atribut ke- $i$ taraf $\mathrm{ke}-j$

$k j \quad=$ taraf ke- $j$ dari atribut ke-I

$m j \quad=$ jumlah atribut ke- $i$

Xij = dummy variable atribut ke- $i$ taraf ke- $j(1=$ taraf muncul; $\quad 0=$ tidak muncul $)$

Nilai kepentingan taraf (NKT) digunakan untuk menentukan pentingnya suatu relatif terhadap taraf yang lain pada suatu atribut. Secara umum model analisis konjoin merupakan bagian dari analisis data multivariate yang dipakai secara spesifik untuk memahami bagaimana responden membangun referensi terhadap suatu produk baik barang maupun jasa dimana metode ini dianggap paling detail untuk mengevaluasi preferensi konsumen dengan atribut dan level yang pilihannya (Malhotra, 2004).

$$
Y=X_{1}+X_{2}+X_{3}+\cdots+X_{n}
$$

Dimana :

Variabel independen $(\mathrm{X} 1, \mathrm{X} 2, \mathrm{X} 3 \ldots \ldots . . \mathrm{Xn})$ adalah faktor maupun level dari masing-masing faktor. Variabel independent berupa data non-metrik, sedangkan Variabel dependent (Y), adalah pereferensi keseluruhan dari responden terhadap level dari masing-masing faktor dari suatu produk.

Nilai relatif penting (NRP) digunakan untuk mengetahui tingkat kepentingan suatu atribut terhadap atribut yang lain. NRP diformulasikan sebagai berikut:

Dimana;

$$
N R P=\frac{U T-U R}{\sum_{J=1}^{K}(U T i-U R j)}
$$

$\mathrm{NRP} \quad=\mathrm{NRP}$ atribut ke- $I$

$\mathrm{UT}_{I}=\mathrm{NKT}$ tertinggi atribut ke- $i$

$\mathrm{UR}_{i} \quad=$ NKT terendah atribut ke- $I$

$\mathrm{K} \quad=$ banyaknya atribut

Produk atau jasa terbaik adalah kombinasi taraf atribut yang memiliki nilai utilitas tertinggi. Kombinasi ini terdiri dari taraf-taraf atribut yang memilki NKT tertinggi. 


\section{Hasil dan Pembahasan}

3.1. Karakteristik Responden Petani

Penelitian ini bertujuan untuk mengetahui karakteristik petani yang menggunakan bibit kelapa sawit bersertifikat dan keterkaitannya dengan preferensi petani kelapa sawit dalam membeli bibit kelapa sawit bersertifikat. Responden yang dianalisis pada penelitian ini berjumlah 100 orang dimana secara keseluruhan merupakan pengguna bibit bersertifikat di Kabupaten Batu Bara. Adapun deskripsi karakteristik responden yang telah diamati antara lain usia, luas lahan, status kepemilikan, pendidikan, dan lama berusahatani. Berikut hasil penelitian karakteristik responden petani kelapa sawit berdasarkan usia, luas lahan, status kepemilikan, pendidikan dan lama berusahatani. Dari penelitian yang telah dilakukan terhadap 100 responden, didapatkan karakteristik responden berdasarkan usia terdapat pada Tabel 1.

Persentase responden petani pengguna bibit bersertifikat berdasarkan usia dibagi atas 4 kelompok diantaranya petani kelompok 20-30 tahun, kelompok 31-40 tahun, kelompok 41-50 tahun dan kelompok diatas 51 tahun. Hasil dari data penelitian dapat diketahui bahwa petani yang menggunakan bibit bersertifikat dengan persentase paling tinggi berada pada rentang usia 51 tahun ke atas.

Tabel 1. Karakteristik Responden Petani

\begin{tabular}{llcc}
\hline Karakteristik & Kelompok & Jumlah & Persentase \\
\hline Usia & 51 tahun ke atas & 30 & $30 \%$ \\
Luas Lahan & $6-10$ Hektar & 42 & $42 \%$ \\
Status Kepemilikan & Milik Pribadi & 100 & $100 \%$ \\
Pendidikan & SMA & 70 & $70 \%$ \\
Lama Berusaha Tani & $11-15$ tahun & 37 & $37 \%$ \\
\hline
\end{tabular}

Hal tersebut menunjukkan bahwa berdasarkan tingkat usia, rentang usia 51 tahun ke atas tetap masih berada dalam masa produktif. Artinya petani kelapa sawit masih mampu bekerja dengan maksimal dan menghasilkan sehingga dapat memenuhi kebutuhan pribadi maupun keluarga. Sebagian besar petani berada pada usia yang tergolong produktif dan hanya terdapat sebagian kecil dari petani yang sudah tua. Dari segi kesehatan dan kemampuan bekerja petani dengan usia produktif mempunyai kemampuan bekerja dan beraktifitas yang lebih tinggi dibandingkan dengan yang sudah tidak produktif (Anggreany, 2016).

Seperti yang kita ketahui, lahan merupakan salah satu faktor produksi dimana luas lahan merupakan hal utama dalam berusahatani, sesuai dengan teori yang ada dimana petani memiliki luas lahan yang besar maka semakin besar produktivitas yang dihasilkan dan secara langsung mempengaruhi pendapatan yang diterima. Menurut Soekartawi (2002) luas lahan pertanian akan mempengaruhi skala usaha, dan skala usaha ini pada akhirnya akan mempengaruhi efisiensi atau tidaknya suatu usaha pertanian. Data hasil penelitian berdasarkan luas lahan menunjukkan bahwa persentase tertinggi dari luas lahan yang dimiliki petani pengguna bibit bersertifikat berada pada 6 - 10 hektar. Dengan luas lahan yang cukup besar maka penggunaan faktor produksi akan cukup mudah diawasi, penggunaan tenaga kerja efisien dan modal tidak terlalu besar.

Karakteristik status kepemilikan lahan kebun kelapa sawit berdasarkan hasil penelitian yang sudah dihimpun didapat bahwasanya 100 persen seluruhnya adalah milik pribadi petani. Disini petani tidak akan menggelontorkan biaya sewa tanah sehingga sepenuhnya modal yang dipunya akan difokuskan ke lahan milik sendiri (Pinem dan Pratiwi, 2020).

Dari hasil analisis berdasarkan tingkat pendidikan, 70 persen petani kelapa sawit di Kabupaten Batu Bara hanya sampai di bangku SMA. Pendidikan formal yang ditempuh oleh responden berbanding lurus terhadap pola pikir dalam menanggapi inovasi-inovasi baru yang diterimanya serta pengaplikasian langsung di lapangan. Demikian juga dengan pengetahuan responden mudah memahami akan kegunaan dari bibit bersertifikat untuk meningkatkan produktivitas usaha kebun kelapa sawit responden. Tingkat pendidikan yang dimiliki petani mempunyai pengaruh terhadap pola pola pikir dan daya nalar seseorang, biasanya seseorang yang mengenyam pendidikan cukup lama akan lebih rasional dalam bertindak dan menjalankan usahanya (Pinem dan Pratiwi, 2020).

Responden di lokasi penelitian sudah menjalankan usahatani kebun kelapa sawit sekitar 11 sampai dengan 15 tahun. Semakin lama seseorang dalam berusahatani maka si petani cenderung sudah terbiasa dan lebih berpengalaman dalam melakukan usahataninya. Hal ini sesuai dengan penelitian yang dilakukan oleh Emiria (2014) bahwa pengalaman cukup yang dimiliki petani akan melatih kemampuan dan kematangan petani dalam mempertimbangkan 
setiap langkah keputusan yang berkaitan dengan usahatani kelapa sawit yang sedang dijalankan.

\subsection{Hubungan Kombinasi Atribut dengan Preferensi Petani}

Hubungan antara kombinasi atribut dengan preferensi konsumen dapat dilihat pada Tabel 2 dengan nilai Pearson's $R$ yang bernilai 0,892 atau nilai preferensi konsumen yang berpengaruh nyata sebesar 89,2 \%. Hal tersebut menunjukan adanya tingkat korelasi yang kuat, dimana nilai sig sebesar 0,000 yang menunjukkan nilai Hubungan antara kombinasi atribut dengan preferensikonsumen dapat dilihat pada nilai Pearson's $R$ yang bernilai 0,892 atau nilai preferensi konsumen yang berpengaruh nyata sebesar 89,2 \%. Hal tersebut menunjukan adanya tingkat korelasi yang kuat, dimana nilai sig sebesar 0,000 yang menunjukkan nilai signifikansi kuat dan tidak melebihi berdasarkan taraf signifikan sebesar 0,05.

Tabel 2. Uji Korelasi Atribut dengan Preferensi Petani

\begin{tabular}{lcc}
\hline Kriteria & Value & Sig. \\
\hline Pearson's R & 0,892 & 0,000 \\
Kendall's tau & 0,683 & 0,000 \\
\hline
\end{tabular}

Uji ketepatan prediksi (predictive accuracy) berdasarkan hasil konjoin bertujuan untuk mengetahui tingkat keeratan hubungan antar variabel yang dinyatakan dengan koefisien korelasi. Dengan ini untuk memprediksi seberapa kuat hubungan predictive accuracy nya. Dari hasil korelasi didapatkan angka korelasi Person's $R$ maupun Kendall'sTau menghasilkan angka yang kuat yaitu 0,89 dan 0,68. Kriteria tingkat keeratan koefisien korelasi dengan nilai koefisien korelasi sebesar 0,76 s/d 0,99 artinya mempunyai hubungan sangat kuat (Sarwono, 2015).

Pada uji signifikansi korelasi diatas menghasilkan signifikansi 0,000 lebih kecil dari 0,05 maka korelasi keenam atribut tadi memiliki nilai signifikansi yang sangat kuat. Dengan demikian maka preferensi dari 100 responden layak dianalisis lebih lanjut untuk menganalisis preferensi petani kelapa sawit dalam membeli bibit bersertifikat di Kabupaten Batu Bara.

Pada hasil uji validitas dengan uji korelasi pearson pada Tabel 3 diatas diketahui bahwa tiap-tiap variabel pertanyaan memiliki hubungan yang signifikan terhadap total skor sehingga dapat dikatakan instrumen penelitian ini adalah valid dan dapat dilakukan pengujian selanjutnya.

Tabel 3. Hasil Uji Validitas ( Uji Korelasi Pearson)

\begin{tabular}{|c|c|c|c|}
\hline \multicolumn{2}{|c|}{ Case Processing Summary } & $\mathrm{N}$ & $\%$ \\
\hline Cases & Valid & 100 & 100 \\
\hline & Excluded $^{\mathrm{a}}$ & 0 & 0 \\
\hline & Total & 100 & 100 \\
\hline
\end{tabular}

Uji reabilitas berfungsi untuk meninjau sejauh mana suatu alat ukur dapat diandalkan sehingga hasil yang diperoleh terbebas dari adanya kesalahan pengukuran. Pada program SPSS versi 25 yang saya gunakan, dilakukan penghitungan nilai dengan metode Cronbach Alpha dimana kuesioner dikatakan terbebas dari kesalahan pengukuran jika nilai Cronbach Alpha lebih besar dari 0,60. Berdasarkan hasil pada Tabel 4 diatas diketahui hasil nilai Cronbach Alpha sebesar 0,623, dengan demikian dapat dikatakan bahwa instrumen alat ukur penelitian ini telah reliable. Sejalan dengan penelitian Aiman (2017) menyatakan Hasil uji reliabilitas menggunakan rumus Conbroach Alpha dengan hasil 0,688. Menurut teori Conbroach Alpha penelitian dinyatakan reliable apabila hasil dari nilai Conbroach Alpha lebih besar daripada 0,6. Sehingga, data-data preferensi konsumen terhadap produk ikan tongkol dapat dikatakan reliabel.

Tabel 4. Hasil Uji Reabilitas (Cronbach Alpha)

Reliability Statistic

Cronbach's alpha

$\mathrm{N}$ of items

0,623

33 


\subsection{Nilai Kegunaan (Utility) terhadap Preferensi Petani}

Dari 32 kombinasi yang diajukan kepada responden yaitu petani bibit bersertifikat saat melakukan penelitian di lapangan, petani akan mulai memilih kira-kira kombinasi yang manakah yang sesuai dengan keinginan dan kepuasan mereka dengan menggunakan skala likert 1 (sangat tidak suka) sampai dengan 5 (sangat suka) dimana kombinasi produk berdasarkan level pada masing-masing atribut yang sudah ditentukan diatas. Kombinasi didapatkan dengan menggunakan orthogonal design di program SPSS 25. Dapat dilihat pada Tabel 5.

Tabel 5. Nilai Kegunaan (Utility) Pada Setiap Level Atribut

\begin{tabular}{|c|c|c|c|}
\hline & & $\begin{array}{l}\text { Utilities } \\
\text { Utility Estimate }\end{array}$ & Std. Error \\
\hline \multirow{4}{*}{ Jenis bibit } & Dumpy (ppks) & 0,573 & .186 \\
\hline & SP540 (ppks) & 0,094 & .186 \\
\hline & MTGano (socfindo) & $-0,045$ & .186 \\
\hline & Lonsum & $-0,622$ & .186 \\
\hline \multirow{3}{*}{$\begin{array}{l}\text { Ukuran } \\
\text { bibit }\end{array}$} & kecambah & $-0,136$ & .143 \\
\hline & umur 3 bulan & 0,113 & .168 \\
\hline & > 9 bulan & 0,023 & .168 \\
\hline \multirow{6}{*}{ Harga } & Rp 7.500 & 0,664 & .208 \\
\hline & Rp 10.500 & $-0,024$ & .208 \\
\hline & Rp 15.000 & 0,870 & .272 \\
\hline & Rp 19.000 & $-0,889$ & .272 \\
\hline & Rp 30.000 & $-0,506$ & .272 \\
\hline & Rp 39.000 & $-0,115$ & .272 \\
\hline \multirow{3}{*}{ Promosi } & $10 \%$ & $-0,095$ & .143 \\
\hline & $25 \%$ & 0,055 & .168 \\
\hline & $50 \%$ & 0,040 & .168 \\
\hline \multirow{3}{*}{ Akses } & Sangat mudah & 0,102 & .143 \\
\hline & mudah & $-0,152$ & .168 \\
\hline & cukup mudah & 0,050 & .168 \\
\hline \multirow{3}{*}{ Tipe Lahan } & Datar & $-0,292$ & .143 \\
\hline & Bergelombang & 0,549 & .168 \\
\hline & Pasang Surut & $-0,257$ & .168 \\
\hline (Constant) & & 2,945 & .134 \\
\hline
\end{tabular}

Nilai utilitas jenis bibit bersertifikat terdiri dari empat level atribut dengan nilai sebagai berikut: bibit Dumpy (PPKS) 0.573, bibit SP 540 (PPKS) 0.094, bibit MT Gano (Socfindo) -0.045 dan bibit Lonsum -0.622 . Pada atribut jenis bibit bersertifikat bernilai positif yaitu pada jenis Dumpy dan SP 540 dimana keduanya merupakan bibit bersertifikat keluaran Pusat Penelitian Kelapa Sawit (PPKS). Level atribut ini menjadi salah satu pertimbangan responden petani kelapa sawit di Batu Bara. Hal ini sesuai dengan di lapangan bahwa rata-rata petani lebih banyak menggunakan bibit keluaran Pusat Penelitian Kelapa Sawit (PPKS). Tetapi pada level atribut jenis benih MT Gano Socfindo dan Lonsum menunjukan utilitas yang negatif dimana kedua level atribut tidak begitu diminati oleh responden.

Pada atribut ukuran bibit terdiri dari tiga level yaitu kecambah, 3 bulan, dan diatas 9 bulan. Hasil penelitian menunjukan bahwa level atribut dengan ukuran 3 bulan bernilai 0.113 dan diatas 9 bulan bernilai 0.023 dimana taraf atribut ini menjadi pertimbangan responden dalam membeli bibit bersertifikat. Namun untuk ukuran kecambah bernilai - 0.136 menunjukan level yang tidak diminati oleh responden.

Nilai utilitas harga didapatkan bahwa range harga bibit bersertifikat yang diminati responden yaitu pada harga Rp.7.500 (0.664) dan harga Rp.15.000 (0.870). Selebihnya untuk harga Rp. 10.500 (-0.024), Rp. 19.000 (-0.889), Rp. 30.000 (-0.506) dan Rp. 39.000 (-0.115) menunjukan nilai yang negatif yang berarti taraf atribut ini tidak diminati oleh responden. Untuk nilai utilitas promosi, hasil penelitian menunjukkan nilai utilitas promosi sebesar 10\% (-0.095), $25 \%(0.055)$ dan $50 \%(0.040)$. Artinya bahwa promosi yang diharapkan petani kelapa sawit dalam membeli bibit bersertifikat pada range $25 \%$ s/d 50\%. Perusahaan bibit bersertifikat dapat memberikan promosi kepada petani apabila mereka membeli dalam jumlah yang banyak.

Nilai utilitas kemudahan akses benih yang bernilai positif paling tinggi yaitu sangat mudah (0.102) dalam mengakses benih bersertifikat. Selama ini akses mendapatkan bibit harus melalui prosedur yang menurut petani cukup rumit sehingga petani berharap ke depannya akan semakin 
dipermudah. Artinya semakin mudah akses bibit maka penggunaan bibit bersertifikat akan semakin tinggi.

Nilai utilitas tipe lahan yang bernilai positif yaitu pada tipe lahan bergelombang (0.549) yang paling diminati oleh responden. Sedangkan untuk tipe lahan datar (-0.292) dan pasang surut $(-0.257)$ bernilai negatif dimana ini menunjukkan kurangnya minat responden. Hasil penelitian ini mewujudkan inovasi produk bibit bersertifikat sebagai upaya meningkatkan permintaan konsumen serta membuat inovasi baru untuk bibit bersertifikat sesuai dengan yang diinginkan oleh konsumen di pasaran. Sehingga produsen bibit bersertifikat diharapkan mampu menciptakan strategi marketing yang baru untuk mendapatkan perhatian konsumen benih kelapa sawit bersertifikat.

Berdasarkan rumus utilitas analisis konjoin, preferensi keseluruhan konsumen terhadap bibit bersertifikat di Kabupaten Batu Bara yaitu sebesar penjumlahan:

Dimana :

$$
\begin{gathered}
\mathrm{Y}=\mathrm{X} 1+\mathrm{X} 2+\mathrm{X} 3+\mathrm{X} 4+\mathrm{X} 5+\mathrm{X} 6+\text { constant } \\
\mathrm{Y}=0,573+0,113+0,870+0,055+0,102+0,549+2,945 \\
\text { Total Utility }=5,207
\end{gathered}
$$

\section{Y: total utility}

$\mathrm{X} 1$ : nilai utility atribut jenis bibit

X2: nilai utility atribut ukuran bibit

X3: nilai utility atribut harga

X4: nilai utility atribut promosi

X5: nilai utility atribut kemudahan akses

X6: nilai utility atribut tipe lahan

Constant: nilai constant dalam analisis

Dari pemaparan diatas dapat dikatakan bahwa kombinasi dari level-level atribut dapat menghasilkan preferensi yang tinggi dan memberikan utilitas tertinggi bagi konsumen bibit bersertifikat di Kabupaten Batu Bara. Analisa hasil penelitian preferensi petani benih bersertifikat yang sangat disukai yaitu benih bersertifikat dengan atribut jenis Dumpy PPKS, umur 3 bulan, kisaran harga Rp.15.000, mendapatkan promosi dari produsen benih sebesar $25 \%$, sangat mudah dalam mengakses benih bersertifikat, dan benih bersertifikat dapat ditanam di tipe lahan bergelombang. Kombinasi taraf atribut terdapat pada kombinasi nomor 8 (delapan).

\subsection{Tingkat Kepentingan terhadap Atribut Bibit Bersertifikat}

Tingkat kepentingan atribut tertinggi yang menjadi pertimbangan petani dalam membeli bibit bersertifikat di Kabupaten Batu Bara adalah harga bibit $(34,5 \%)$, jenis bibit bersertifikat $(21,05 \%)$, tipe lahan $(16.85 \%)$. Sedangkan ukuran bibit $(9.36 \%)$, kemudahan akses benih $(9.31 \%)$, dan adanya promosi dari produsen $(8.92 \%)$ tidak selalu menjadi pertimbangan bagi petani. Preferensi petani dalam membeli bibit kelapa sawit memlilih harga bibit sebagai atribut yang paling diutamakan ketika melakukan pembelian bibit bersertifikat di Kabupaten Batu Bara. Hasil Penelitian bersamaan dengan penelitian yang dilakukan Widiyanto (2016) dimana atribut harga merupakan atribut yang paling diutamakan ketika melakukan pembelian buah apel. Hal ini menunjukkan bahwa preferensi konsumen lebih mengarah kepada atribut buah apel lokal yang dinilai lebih baik.

Tabel 6. Tingkat Kepentingan (Importance values) terhadap Atribut

\begin{tabular}{lc}
\hline & Importance Values \\
Atribut Jenis & 21,050 \\
Atribut Ukuran & 9,362 \\
Atribut Harga & 34,500 \\
Atribut Promosi & 8,926 \\
Atribut Kemudahan akses & 9,310 \\
Atribut Tipe lahan & 16,852
\end{tabular}

Averaged Importance Score

Sejalan dengan teori yang dikemukakan oleh Gudono (2015) bahwa atribut dengan tingkat kepentingan (importance values) terbesar atau tertinggi merupakan atribut yang lebih diperhatikan oleh konsumen daripada atribut lainnya dan merupakan atribut yang paling mempengaruhi konsumen dalam mengambil keputusan untuk membeli. 


\section{Simpulan}

Dari pemaparan diatas dapat dikatakan bahwa kombinasi dari level-level atribut memberikan preferensi dan utilitas tertinggi bagi petani bibit bersertifikat di Kabupaten Batu Bara. Hasil penelitian menunjukkan preferensi petani bibit bersertifikat yang sangat disukai yaitu benih bersertifikat dengan atribut jenis Dumpy keluaran PPKS, umur 3 bulan, kisaran harga Rp.15.000, mendapatkan promosi dari produsen benih sebesar 25\%, sangat mudah dalam mengakses benih bersertifikat, dan benih bersertifikat dapat ditanam di tipe lahan bergelombang. Hal ini dibuktikan ketika petani menggunakan bibit tersebut hasilnya berpengaruh positif terhadap hasil panen petani yaitu produktivitas meningkat dan cenderung stabil tiap tahun.

Preferensi petani dalam membeli bibit kelapa sawit memilih harga bibit sebagai atribut yang paling diutamakan ketika melakukan pembelian bibit bersertifikat di Kabupaten Batu Bara dimana harga merupakan poin penting dalam suatu produk.

\section{Acknowledgement}

Peneliti berterimakasih kepada Direktorat Riset dan Pengabdian Masyarakat, Direktorat Jenderal Penguatan Riset dan Pengembangan Kementrian Riset, Teknologi dan Pendidikan Tinggi yang telah mendukung dan mendanai penelitian ini.

\section{Pustaka}

Aiman, A., Handaka, A dan Lili, W. 2017. Analisis Preferensi Konsumen Dalam Pengambilan Keputusan Membeli Produk Olahan Perikanan Di Kota Tasikmalaya (Studi Kasus Di Pasar Tradisional Cikurubuk, Kec. Mangkubumi). Jurnal Perikanan dan Kelautan Vol.8 No 1.

Anggreany, S., Muljono, P., \& Sadono, D. (2016). Partisipasi Petani dalam Replanting Kelapa Sawit di Provinsi Jambi. Jurnal Penyuluhan, 12(1).

Ariyanti, M., Natalia, G dan Suherman, C. 2017. Respons Pertumbuhan Bibit Kelapa Sawit (Elaeis guineensis Jacq.) terhadap Pemberian Pupuk Organik Asal Pelepah Kelapa Sawit dan Pupuk Majemuk NPK. Jurnal Agrikultura 2017, 28 (2): 64-67.

Bappeda Kabupaten Batu Bara. 2013. Batu Bara dalam Angka. https:// bappeda.kabupatenbatubara.id/. (diakses pada tanggal 5 Januari 2020).

Emiria, F., \& Purwandari, H. (2015). Pengembangan Pertanian Organik di Kelompok Tani Madya, Desa Kebonagung, Kabupaten Bantul, Daerah Istimewa Yogyakarta. Jurnal Penyuluhan, 10(2).

Gudono. (2015). Analisis Data Multivariat, Yogyakarta : BPFE.

Kariyasa, I Ketut. 2015. Analisis Kelayakan Finansial Penggunaan Bibit Bersertifikat Kelapa Sawit di Provinsi Kalimantan Barat. Jurnal Agro Ekonomi 3 (2): 141-159.

Naibaho, Toha Totor. 2019. Analisis Perbedaan Tingkat Pendapatan Terhadap Preferensi Konsumen Kopi Lokal Sumatera di Kota Medan. Jurnal Penelitian Pendidikan Sosial Humaniora Vol. 4. No. 1 Mei 2019. Balai Besar Pelatihan Pertanian (BBPP) Binuang Kementerian Pertanian.

Kotler, Philip dan AB Susanto. 2005. Manajemen Pemasaran di Indonesia :Analisis, Perencanaan, Implementasi dan Pengendalian, Edisi 6, Jilid 1, Salemba Empat, Jakarta.

Malhotra, John R Hauser dan Vithala R Rao. 2004. Conjoint Analysis, Related Modeling and Applications. Marketing Research and Modeling: Progress and Prospects, 141-168.

Pinem, L. J., \& Saprida. 2018. Analisis Pengambilan Keputusan Pembelian Petani dalam Memilih Benih Kelapa Sawit Bersertifikat dan nonsertifikat di Kabupaten Labuhan Batu Utara. Journal of Agribussiness Science 2 (1).

Pinem, L.J., dan Pratiwi, M. 2020. Faktor-Faktor Pendorong Petani dalam Memilih Benih Kelapa Sawit (Elaeis guineensis) Bersertifikat dan Nonsertifikat. Jurnal Agribisnis Lahan Kering Vol 5(1) hal: 1-4: Agrimor-Januari 2020.

Sarwono, J. 2013. Statistik Multivariat Aplikasi untuk Riset Skripsi. Yogyakarta : CV Andi Offset.

Simarmata, L., R.E.M.F.Osak,E.K.M. Endoh, dan Franky N. S. Oroh .2019. Analisis Preferensi Konsumen Dalam Membeli Daging Broiler Di Pasar Tradisional Kota Manado (Studi Kasus "Pasar Pinasungkulan Karombasan. Jurnal Zootec Vol. 39 No. 2 : 194-202.

Sumarwan, U. 2011. Perilaku Konsumen. Edisi Kedua. Bogor : Ghalia Indonesia.

Soekartawi. 2002. Prinsip Dasar Manajemen Pemasaran Hasil-Hasil Pertanian Teori dan Aplikasinya. Jakarta. PT Raja Grafindo Persada. Hal 134.

Wijaya, Tony. 2009. Analisis Data Penelitian menggunakan SPSS. Yogyakarta: Universitas Atmajaya. 
Widiyanto, N,A., Adhi, A, K., dan Daryanto, H, K. 2016. Atribut-Atribut yang Memengaruhi Sikap dan Preferensi Konsumen dalam Membeli Buah Apel di Kota Surabaya. Jurnal Ilmu Keluarga dan konsumen Vol.9, No.2 : 136-1.

Simarmata, L., R.E.M.F.Osak,E.K.M. Endoh, dan Franky N. S. Oroh .2019. Analisis Preferensi Konsumen Dalam Membeli Daging Broiler Di Pasar Tradisional Kota Manado (Studi Kasus "Pasar Pinasungkulan Karombasan. Jurnal Zootec Vol. 39 No. 2 : 194-202.

Sumarwan, U. 2011. Perilaku Konsumen. Edisi Kedua. Bogor : Ghalia Indonesia.

Soekartawi. 2002. Prinsip Dasar Manajemen Pemasaran Hasil-Hasil Pertanian Teori dan Aplikasinya. Jakarta. PT Raja Grafindo Persada. Hal 134.

Wijaya, Tony. 2009. Analisis Data Penelitian menggunakan SPSS. Yogyakarta: Universitas Atmajaya.

Widiyanto, N,A., Adhi, A, K., dan daryanto, H, K. 2016. Atribut-Atribut yang Memengaruhi Sikap dan Preferensi Konsumen dalam Membeli Buah Apel di Kota Surabaya. Jurnal Ilmu Keluarga dan konsumen Vol.9, No.2: 1 . 